Lawrence Livermore National Laboratory

University of California, Livermore, California 94550

UCRL-ID-142934

\title{
Livermore Site Southeast Corner VOC Source Study-B419/511 Area
}

Authors

P.A. Krauter

M.P. Maley*

G.F. Aarons*

S. Gregory

\section{June 1, 2000}

*Weiss Associates, Emeryville, California

Environmental Protection Department

Environmental Restoration Program and Division 


\section{DISCLAIMER}

This document was prepared as an account of work sponsored by an agency of the United States Government. Neither the United States Government nor the University of California nor any of their employees, makes any warranty, express or implied, or assumes any legal liability or responsibility for the accuracy, completeness, or usefulness of any information, apparatus, product, or process disclosed, or represents that its use would not infringe privately owned rights. Reference herein to any specific commercial product, process, or service by trade name, trademark, manufacturer, or otherwise, does not necessarily constitute or imply its endorsement, recommendation, or favoring by the United States Government or the University of California. The views and opinions of authors expressed herein do not necessarily state or reflect those of the United States Government or the University of California, and shall not be used for advertising or product endorsement purposes.

This work was performed under the auspices of the U. S. Department of Energy by the University of California, Lawrence Livermore National Laboratory under Contract No. W-7405Eng-48. 


\title{
Livermore Site Southeast Corner VOC Source Study-B419/511 Area
}

\author{
Authors
}

P.A. Krauter

M.P. Maley*

G.F. Aarons*

S. Gregory

\section{June 2000}

*Weiss Associates, Emeryville, California

\section{Environmental Protection Department} Environmental Restoration Program and Division 


\section{Table of Contents}

1. Introduction 1

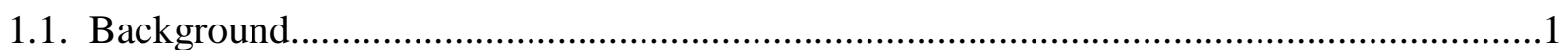

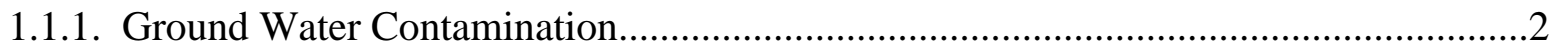

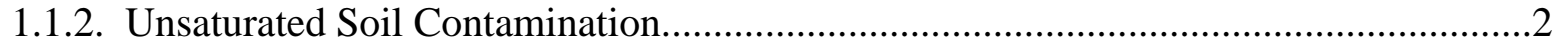

1.2. Passive Soil Gas Study: Preliminary Source Investigation...................................................

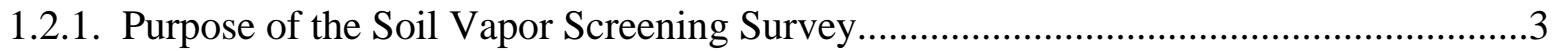

1.2.2. Methodology: Soil Vapor Survey.........................................................................

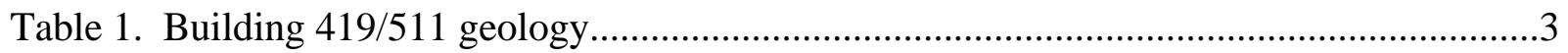

1.3. Results and Discussion: Vapor Screening Survey, Hydrogeologic Analysis and Contaminant Degradation Pathways......................................................................................

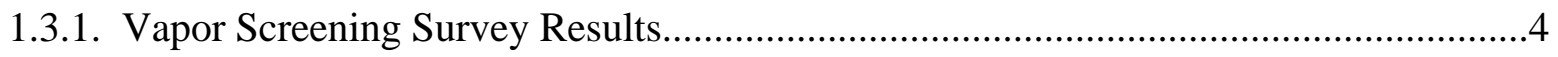

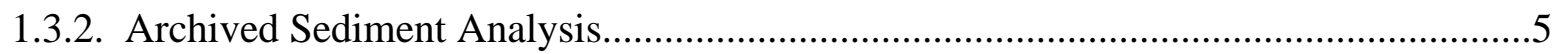

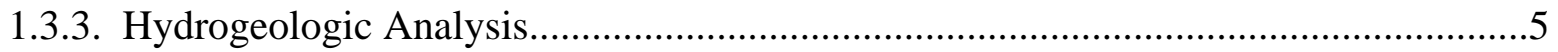

1.3.4. Bioremediation and Natural Attenuation Potential.......................................................

Table 2. Standard ground water sample versus Gore-Sorber ${ }^{\mathrm{TM}}$ sample analysis of

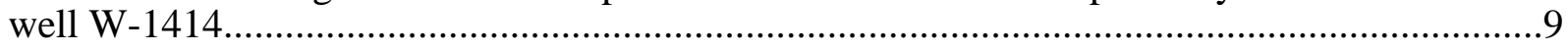

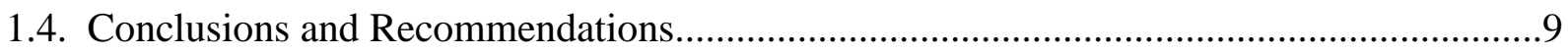

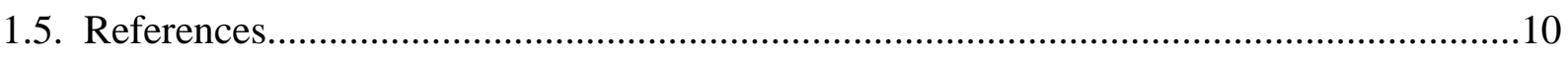

\section{List of Figures}

Figure 1. Location of the Building 419/511 Study Area.

Figure 2. HSU 3A TCE concentrations, 4th quarter 2000.

Figure 3. HSU 3B TCE concentrations, 4th quarter 2000.

Figure 4. Volatile organic compounds (VOCs) soil vapor contours around Buildings 419 and 511, LLNL.

Figure 5. Tetrachloroethene (PCE) soil vapor contours around Buildings 419 and 511, LLNL.

Figure 6. Trichloroethene (TCE) soil vapor contours around Buildings 419 and 511, LLNL.

Figure 7. 1989 total VOCs soil vapor survey.

Figure 8. Near surface soil (0-12 ft) plume history analysis for total VOCs (data from 1984 and 1989).

Figure 9. The first saturated hydrostratigraphic unit in the southeast portion of LLNL.

Figure 10. West-East cross section through Buildings 411, 419 and 511. 
Figure 11. HSU 3A, Isopach of moderate to very high permeability sediments. Isopachs represent the cumulative thickness of sediments, such as sands, within an HSU.

Figure 12. HSU 3B, Isopach of moderate to very high permeability sediments.

Figure 13. HSU 5, Isopach of moderate to very high permeability sediments. 


\section{Introduction}

A passive soil gas study was conducted in the Building 419/511 (B419/511) area to screen for volatile organic compound (VOC) source locations in June 2000. Results of this study are presented with the most recent ground water contaminant plume maps, as well as the historic surface vapor analysis and soil contamination maps. Limited analytical data exists for the area directly north and west of B419. Because of extensive VOCs in ground water directly under the north end of B419, it is important to determine if the contaminant plume migrated to that location or if it originated from activities at B419. The results of this and previous investigations will aid in defining (1) the source(s) of contamination, (2) the placement and management of future remediation wells, and (3) remediation strategies.

A brief description of the building's function and contamination summary is presented in Section 1.1. Section 1.2 presents the methodology used for the passive soil gas study. Section 1.3 is a discussion of the passive soil gas study and the hydrogeologic analysis. Concluding remarks and recommendations for future source investigations and remediation designs are found in Section 1.4.

\subsection{Background}

B419 is located in the southeastern quadrant of the Livermore Site, northwest of Building 518 (Fig. 1). During the Navy era, the area around B419 was used for aircraft assembly, overhaul, and maintenance where solvents including trichloroethene (TCE), tetrachloroethene (PCE), and carbon tetrachloride were used and possibly washed into the storm drains during rainstorms. Later, the Navy used the 7,860- $\mathrm{ft}^{2}$ building as a paint and dope shop. The building was then restructured as an assay lab used by Health Chemistry through 1975, and subsequently as a decontamination and reduction facility used by Hazardous Waste Management.

The theory that B419 is a source area is supported by the past activities in the building. From 1975 until about 1990 the building was used by LLNL for equipment decontamination, and hazardous and mixed waste treatment activities. Mixed waste was detected in soil samples from the north side of the building. The samples contained mercury, uranium and VOCs. Room 167 of B419 shares the outside wall with the north yard. In room 167 there is a walk-in hood and a site where once stood a vapor degreaser. This area was used to clean and decontaminate mercury diffusion pumps for about 20 years. Both mercury and uranium were found in the flooring and in sediments under the floor in 1995. Cracks and patched areas were observed in the cement floor of room 167 during building closure cleanup activities in 1996. It is suspected, due to the prior facility operations and floor damage, that the contamination seeped through the floor and into the subsurface. Other potential conduits for contamination include underground mixed waste storage tanks and transfer lines. The two underground mixed waste storage tanks were removed in 1995 from the southwest side of the building (BeLue and Finley, 1999).

Building 412 (B412) located northeast of B419, was used for aircraft inspection during the Navy era and uranium metallurgical research in the 1950s and 1960s. The area to the east of B412 and north of B419 was used to store solid radioactive waste. 
Building 419 is scheduled for decontamination and decommissioning within the next few years and LLNL has submitted a closure plan to the Department of Toxic Substances Control (DTSC). The closure will be conducted under Resource Conservation and Recovery Act (RCRA).

\subsubsection{Ground Water Contamination}

The TCE in the ground water under the north end of B419 exceeds the State and Federal Maximum Contaminant Level (MCL) of $5 \mu \mathrm{g} / \mathrm{L}$; however, monitor wells in the immediate vicinity of B419 do not contain appreciable levels of tritium or metals. The B419 area may be an important source of TCE to the Treatment Facility 406 area, southwest of the building. Wells adjacent to B419 (W-1414, SIP-419-201, and SIP-419-202) contain VOC concentrations up to 3,000 $\mu \mathrm{g} / \mathrm{L}$ in hydrostratigraphic unit (HSU) 3A (Figs. 2 and 3). HSU 3A is the first saturated unit underlying B419 (Table 1). HSU 3B well SIP-419-101, located to the west of B419 has a total VOC concentration of $40 \mu \mathrm{g} / \mathrm{L}$ (Fig. 3). Ground water from HSU 5 well W-1413, located northwest of B419 is below the MCL.

TCE is also found in the ground water under the south end of B511. Two HSU 5 wells, W622 and W-205 located on the western and eastern corners slightly south of B511 contain elevated levels of TCE, 110 and $780 \mu \mathrm{g} / \mathrm{L}$, respectively. Well SIP-511-101, located to the west of B511 in HSU 3A, contain concentrations of carbon tetrachloride, PCE, and TCE of 240, 9.4, and $310 \mu \mathrm{g} / \mathrm{L}$, respectively. HSU 3B well SIP-511-102, also located to the west of B511, contains only trace levels of carbon tetrachloride and TCE ( 7.5 and $6.3 \mu \mathrm{g} / \mathrm{L}$, respectively).

\subsubsection{Unsaturated Soil Contamination}

Sediment samples in the upper $30 \mathrm{ft}$ from the B419 area contained tritium and VOCs (primarily TCE, PCE, carbon tetrachloride, and 1,2-dichloroethane). Soil samples collected in June 1996 during the excavation and removal of the pipes on the west side of B419 were analyzed for metals, and radionuclides (BeLue and Finley, 1999). Only mercury was over the California Hazardous Waste total threshold level concentration (TTLC) limits; no other metals data exceeded limits. Tritium radioactivity in one shallow soil sample exceeded criteria limit of 45,000 pCi/g.

Unlike B419, the first saturated zone under the east end of B511 occurs in HSU 5. The VOC concentrations in HSU 5 well W-622 located at the southeast corner of B511 is 1,200 $\mu \mathrm{g} / \mathrm{L}$. The VOC concentrations in HSU 3A piezometer well SIP-511-101, located west of the building is approximately $600 \mu \mathrm{g} / \mathrm{L}$. HSU 3B well SIP-511-102, also located to the west of the building, has a ground water VOC concentration of $16 \mu \mathrm{g} / \mathrm{L}$. Most of the VOC contamination is PCE (about $70 \%)$ at this location. 
Table 1. Building 419/511 geology.

\begin{tabular}{|c|c|c|}
\hline $\begin{array}{c}\text { Hydrostratigraphic } \\
\text { unit }\end{array}$ & $\begin{array}{l}\text { Depth below ground } \\
\text { surface }(\mathrm{ft})\end{array}$ & Sediment description \\
\hline 1B & 0 to 37 & $\begin{array}{l}\text { Thick, yellow-brown layers of silty sand and } \\
\text { gravel with thin interbedded layers of clayey } \\
\text { silt }\end{array}$ \\
\hline 2 & 37 to 90 & $\begin{array}{l}\text { Yellow-brown clayey silt with minor } \\
\text { interbedded sand }\end{array}$ \\
\hline $3 \mathrm{~A}$ & 90 to 99 & $\begin{array}{l}\text { Fine-grained but may contain several thin } \\
\text { sandy layers }\end{array}$ \\
\hline 3B & 107 to 115 & $\begin{array}{l}\text { Mostly fine-grained sediment with a single } \\
\text { higher-permeability sand; absent beneath the } \\
\text { east end of B511 }\end{array}$ \\
\hline 4 & $\begin{array}{l}\text { Absent beneath B419 } \\
\text { and B511 }\end{array}$ & \\
\hline 5 & $110-120$ to 175 & $\begin{array}{l}\text { Mostly fine-grained sediment with a few sand } \\
\text { and gravel layers, characterized by a change to } \\
\text { mottled-colored sediments }\end{array}$ \\
\hline
\end{tabular}

\subsection{Passive Soil Gas Study: Preliminary Source Investigation}

\subsubsection{Purpose of the Soil Vapor Screening Survey}

The purpose of the soil vapor screening survey was to locate potential contaminant sources in the B419/511 area. This information will be used to determine the location of ground water or soil vapor treatment facilities.

\subsubsection{Methodology: Soil Vapor Survey}

Prior to beginning the soil vapor survey, an integrated work sheet (IWS-637), a utilities clearance report, and a soil excavation permit were generated. The soil gas sampler chosen for the survey was a Gore-Sorber ${ }^{\mathrm{TM}}$ module. This module is constructed of a hollow insertion/retrieval cord constructed of Gore-texePTFE ${ }^{\mathrm{TM}}$, and expanded polytetrefluorethylene structure. Inside the cord are small hollow ePTFE tubes filled with sorbent material that are sealed at both ends. Soil vapor transfers through the insertion/retrieval cord and into the sorbent-filled collectors.

The Gore-Sorber ${ }^{\mathrm{TM}}$ modules were installed by drilling through the concrete or paved surfaces then driving a tile probe to $3 \mathrm{ft}$ below the ground surface. The modules were then inserted into the hole so that the collection tip was located at the bottom of the hole. A cork was attached to the sorber module for retrieval and to seal the hole in order to prevent loss of VOCs or mixing with surface air.

The sample spacing was dictated by utility locations, traffic patterns and building entrances. The industrial use and operational practices were considered in the soil gas sample locations. In general, the soil gas samples were placed about 25-50 ft apart from each other in parallel transects running north south and east west. 
The standard modules were left in the ground for 2 weeks (June 15-29, 2000) then retrieved and analyzed for selected VOCs. The modules were thermally desorbed and the samples were analyzed by gas chromatography/mass spectroscopy by the manufacturer. Internal quality assurance controls included instrument, manufacturing and method blanks, in addition to calibration standards and equipment tuning checks.

\subsection{Results and Discussion: Vapor Screening Survey, Hydrogeologic Analysis, and Contaminant Degradation Pathways}

\subsubsection{Vapor Screening Survey Results}

Data from the current survey provides information supporting the theory that the north end of B419 is an important TCE contaminant source location. In addition, data suggest that the areas of contamination near B419 and B511 are from different sources. Our current data set supports the finding of three separate source locations in the B419/511 study area. One source location is slightly west of B513, a former hazardous waste storage area (Fig. 4). Two sample locations southwest and northwest of B513 contained relatively high concentrations of PCE ( 7 $\mu \mathrm{g} / \mathrm{sorber}$, Fig. 5) and low concentrations of TCE ( $0.4 \mu \mathrm{g} / \mathrm{sorber}$, Fig. 6). Just north of B511 the VOC composition is different from the contaminant signature near B513. The four sample locations north of B511 contain high concentrations of TCE (up to $140 \mu \mathrm{g} / \mathrm{sorber}$ ) and low concentrations of PCE ( 0.4 to $1.5 \mu \mathrm{g} /$ sorber). The third source location is a high concentration of PCE (44.9 $\mu \mathrm{g} /$ sorber) and TCE (approx. $20 \mu \mathrm{g} /$ sorber) located in the fenced yard just north of B419.

In general, locations of contamination detected in the Gore-Sorber ${ }^{\mathrm{TM}}$ vapor screening survey were the same as those in the ground water plume maps. A localized area containing high TCE concentrations was detected in the north yard of B419, which is located directly over ground water with high TCE contamination. Although no soil vapor survey had previously been conducted around the B419 area, a 1989 soil vapor study was preformed in the areas north, east and south of B511 (Isherwood et al., 1990). In that study, VOCs were not detected in samples north of the building (Fig. 7). In contrast, the current survey detected TCE contamination north and southeast of B511.

One conclusion from the June screening survey is that three separate source locations exist in the B419/511 area. Also, a small isolated area of contamination (2-3 $\mu \mathrm{g}$ VOC/sorber) was located in the fenced yard west of B419 where two hazardous waste tanks resided prior to their removal in the mid-90s. In general, the Gore-Sorber ${ }^{\mathrm{TM}}$ data accurately matched the existing ground water data for the B419 area.

Limited information exists for the ground water beneath B511 and B514 due to the location of building, utilities and roadways. An indication of the ground water contamination under B511 may be estimated by adjacent sampling locations: HSU 5 monitor well W-622 (1,214 VOC $\mu \mathrm{g} / \mathrm{L})$ at the southeast corner of B511, HSU 3A well SIP-511-101 (609 VOC $\mu \mathrm{g} / \mathrm{L})$ now de-watered located just west of B511 and; HSU 3B well SIP-511-102 (16 VOC $\mu \mathrm{g} / \mathrm{L}$ ) also de-watered, located on the east side of B419. The total VOC concentrations in HSU 5 extraction well W-359 located north of B511 doubled (320 to $660 \mu \mathrm{g} / \mathrm{L}$ ) from March 1999 to June 1999 while pumping at $10 \mathrm{gpm}$ to 
portable treatment unit (PTU) 10. Potentially, VOCs from ground water beneath B511 may have been drawn toward well W-359, which is located about $150 \mathrm{ft}$ north of B511.

An identical soil vapor survey was conducted in the B518 area to the southeast of B511 concurrent with the B419/511 survey. Although a discussion of the results are not included here, it is interesting to note that the most northwest sampling location at B518 had a high PCE signature similar to the contaminant signature on the east side of B511. Potentially, there could be a connection between these two areas. This may warrant further soil vapor surveys to investigate vadose zone contamination between B511 and B518.

The presence or absence of pavement (asphalt or concrete) and the porosity of the sediments may influence the usefulness of these soil vapor modules. The present survey may credit its VOC sensitivity, in part, to the asphalt/concrete surface. Future studies should factor these influences into the sampling plan.

\subsubsection{Archived Sediment Analysis}

In a database retrieval (July 2000) of almost 8,000 individual sediment analyses from samples collected from the B419/511 area, no important contaminant source locations were identified. These sediment analyses are of limited value in determining contaminant source areas because of the tendency of a contaminant to move rapidly through coarse-grain sediment and concentrate in the fine-grain sediments. The possibility of missing a location of contamination vertically or horizontally can be significant. The sediment data does not match the source locations outlined in the recent vapor screening survey. However, the plume history analysis (PLUHA) near-surface (0-12 ft) map for VOCs does match the contaminant located on the east side of B511 (Fig. 8). Very limited information is available for the north or west side of B511 or the B419 area.

\subsubsection{Hydrogeologic Analysis}

The hydrogeology of the B419/511 area is complex. In this area, the intersection of the structural and ground water gradients causes a complicated pattern where different HSUs are saturated at a given location (Fig. 9). In Figure 10, the cross section shows that the first saturated HSU varies between HSU 2, 3A, 3B, 4, and 5 in this area. In addition, strong permeability trends are observed with significant zones of low-permeability sediments. These factors strongly influence the ground water flow and contaminant transport in this region. The complex hydrogeology of the southeast corner is currently undergoing a detailed review to include new boreholes and extraction well data. Some changes to the HSU boundaries may result from this reanalysis.

\subsubsection{1. $H S U 2$}

The edge of saturation of HSU 2 forms a northeast-southwest trending line that is located north of B419 and B511. Southeast of this line, HSU 2 is completely unsaturated, whereas northwest of this line, HSU 2 becomes progressively more saturated. HSU 2 is characterized by well-developed sand intervals separated by finer-grained sediments. However, because of the thin saturated thickness, most of these sands are unsaturated. Therefore, the hydraulic interconnection between sand layers within HSU 2 is limited. This results in low transmissivities and low flow rates in HSU 2 wells located in this area. Historically, the ground water flow direction is towards the west- 
northwest with a hydraulic gradient of 0.008 . However, with increased pumping at ground water treatment facilities TFE and TFD, the gradient has rotated to a more northerly direction with a hydraulic gradient of 0.016. Water levels in well W-274 have decreased about $6 \mathrm{ft}$ from 1996 to 2000, mostly due to increased downgradient pumping.

HSU 2 contains TCE, PCE, and carbon tetrachloride in concentrations above their respective MCLs of 5, 5, and $0.5 \mu \mathrm{g} / \mathrm{L}$. The highest concentrations are observed in well $\mathrm{W}-274$ that has recent maximum TCE, PCE, and carbon tetrachloride concentrations of 430, 6.2, and $4.7 \mu \mathrm{g} / \mathrm{L}$. The source of these VOCs appears related to the elevated soil vapor data north of B511 and in the vicinity of B512.

HSU 2 wells were planned to be hooked up to the future TFE-SE treatment facility; however, due to the thin saturated thickness, neither well W-274 nor the newly installed well W-1517 are viable ground water extraction wells due to their low pumping rates. Ground water extraction at a downgradient site is more feasible but this would further dewater the source area and leave VOCs in the unsaturated zone. This may be a good location to review the feasibility of soil vapor extraction to remediate the source area.

\subsubsection{2. $H S U 3 A$}

The edge of saturation of HSU 3A forms a north-northeast trending line between B419 and B511. Southeast of this line, HSU 3A is completely unsaturated, whereas northwest of this line, HSU 3A becomes progressively more saturated. HSU 3A is the uppermost-saturated zone in the B419 area; however, it is unsaturated beneath the B511. Northwest of B419, HSU 3A is overlain by a saturated HSU 2. Fine-grained sediments with local development of sand bodies (Fig. 11) characterize HSU 3A. The fine-grained nature results in low transmissivities and low flow rates in HSU 3A wells located in this area. Historically, the ground water flow direction is toward the westnorthwest with a low hydraulic gradient of 0.003 . However, with increased pumping due to the expanding ground water remediation in TFE and TFD, the gradient has changed. Currently, B419 area is on a ground water divide with water flowing to the northeast and to the west with a hydraulic gradient of about 0.02. The water level at SIP-419-202 decreased about $7 \mathrm{ft}$ from 1996 to 2000, mostly due to increased downgradient pumping.

HSU 3A consists of TCE, PCE, carbon tetrachloride, and 1,2 DCA in concentrations above their respective MCLs of 5, 5, 0.5, and $0.5 \mu \mathrm{g} / \mathrm{L}$. The highest concentrations are observed in SIP-419202 that has recent maximum TCE, PCE, carbon tetrachloride, and 1,2-DCA concentrations of $2,200,190,40$, and $75 \mu \mathrm{g} / \mathrm{L}$, respectively. The source of the VOCs is most likely related to the elevated soil vapor data on the northside of B419.

HSU 3A wells were planned to be hooked up to the TF518 North treatment facility; however, due to the low conductivities from the fine grained sediments, the newly installed well W-1414 exhibits poor pumping rates and is not a viable ground water extraction well. Ground water extraction at a north west downgradient location may be more feasible; however, this would further dewater the source area and leave VOCs in the unsaturated zone. This would be a good location to review the feasibility of soil vapor extraction and/or electro-osmosis to remediate the B419 source area. 


\subsubsection{3. $H S U 3 B$}

A subsurface pinchout limits the horizontal extent of HSU 3B in the B419/511 area. The HSU 3B pinchout forms a nearly north-south trending line between B419 and B511. East of this line, HSU 3B is not present, whereas west of this line, HSU 3B is saturated. HSU 3B is the uppermostsaturated zone south of B419 and B511; however, to the north and west, HSU 3B is overlain by saturated HSUs 2 and 3A. In this area, HSU 3B is characterized by mostly fine-grained sediments with minor sand bodies (Fig. 12). The fine grain nature results in low transmissivities and low flow rates in HSU 3A wells located in this area. The ground water flow direction is toward the westsouthwest; however, the hydraulic gradient has increased from about 0.006 in 1996 to about 0.05 in 2000 due to the increased pumping from remediation efforts at TFE and TFD. The water level at well W-205 decreased about $10 \mathrm{ft}$ from 1996 to 2000, mostly due to increased downgradient pumping.

HSU 3B consists of TCE and carbon tetrachloride in concentrations above their respective MCLs of 5 and $0.5 \mu \mathrm{g} / \mathrm{L}$. The highest concentrations are observed in well W-205 that has maximum concentrations in 2000 for TCE and carbon tetrachloride of 1200 and $3.7 \mu \mathrm{g} / \mathrm{L}$, respectively. The source of these VOCs is most likely related to the elevated soil vapor data on the southwest side of B511 in the vicinity of well W-205. Beneath B419, HSU 3B well SIP-419-101 has TCE and carbon tetrachloride concentrations of 35 and $4.8 \mu \mathrm{g} / \mathrm{L}$, respectively. Although these concentrations are above their respective MCLs, they are significantly lower than the concentrations in the overlying HSU 3A well, SIP-419-202.

HSU 3B southwest of B511 is not currently being treated by any of the ground water treatment facilities. However, poor pumping rates due to the low conductivities from the fine-grain sediments, limits the effectiveness of ground water extraction wells. Ground water extraction at a downgradient location may be feasible; however, this may further dewater the source area and leave VOCs in the unsaturated zone. This may be a good location to review the feasibility of soil vapor extraction and/or electro-osmosis for source area remediation.

\subsubsection{HSU 5}

HSU 5 is saturated over the entire B419/511 area. However; due to the increased pumping from the expanding ground water remediation in TFD, TFE, TF406, and TF518N; ground water levels have dropped by 15 to $20 \mathrm{ft}$ in the southeastern portion of LLNL. HSU 5 is partially saturated in the B511 and B518 areas. HSU 5 becomes locally unsaturated to the east of B511 and B518 under the current high-pumping conditions. The TF518 extraction well, W-112, has not operated for much of 2000 due to low flow rates caused by the lowered ground water. It pumped as high as $15 \mathrm{gpm}$ in 1998. HSU 5 contains significant high-permeability sands to the north, east, and south of B511 (Fig. 13); however, a zone of low permeability within HSU 5 is located west of B511 in the B419 area. These permeability trends exert a strong control of ground water flow directions. The hydraulic gradients in HSU 5 have been variable in the past and this is more accentuated with the increased ground water pumping.

HSU 5 contains TCE, PCE, carbon tetrachloride, and 1,1 dichloroethene (DCE) in concentrations above their respective MCLs of 5, 5, 0.5, and $6 \mu \mathrm{g} / \mathrm{L}$. The VOCs in HSU 5 appear to be related to four primary source areas that include the areas (1) near B518, (2) west of B511 and near B514, (3) north of B511, and (4) near B612. The highest concentrations observed in well 
W-622 in 1999 for TCE, PCE, carbon tetrachloride, and 1,1-DCE are 860, 110, 150, and $40 \mu \mathrm{g} / \mathrm{L}$, respectively. The highest concentrations observed in well W-359 in 2000 for TCE, PCE, carbon tetrachloride and 1,1-DCE are 490,37,33, and $25 \mu \mathrm{g} / \mathrm{L}$, respectively. VOC maps indicate the presence of another source area in the B612 area that is contributing significant mass to HSU 5; however, the ground water is not well characterized in this area.

The B518 area has undergone active remediation for several years by extraction at well W-112. TCE concentrations in well W-112 have dropped from $1,900 \mu \mathrm{g} / \mathrm{L}$ in 1987 to about $35 \mu \mathrm{g} / \mathrm{L}$ in 2000. However, the concentrations in well W-622, on the southeast corner of B511 and north of well $\mathrm{W}-112$, have not changed significantly during this period. The most likely cause is that this location is within the low-permeability sediments of HSU 5. In response to well W-112 pumping, the high-permeability sediments have shown significant decreases in VOCs whereas the lowpermeability areas have remained stable. North of B511 is the planned TFE-SE treatment facility that will extract from HSU 5 well W-359. Well W-359 is located in the high-permeability area of HSU 5 and is anticipated to produce results similar to well W-112 with ground water extraction. The low-permeability areas of HSU 5 near the B511 area and well W-622 may be good locations to review the feasibility of soil vapor extraction and/or electro-osmosis to remediate the source area. Additional characterization work is required to determine the nature of any potential source areas in the B612 area, and to determine the remediation alternatives required there.

\subsubsection{Bioremediation and Natural Attenuation Potential}

In some ground water, PCE and TCE can undergo reductive dechlorination catalyzed by anaerobic bacteria. Microbial anaerobic degradation pathways of PCE and TCE are potential remediation mechanisms for ground water. For instance, an anaerobic PCE degradation pathway reductively dehalogenates TCE to cis-1,2-dichloroethene and trans-1,2 dichloroethene, which then degrades to vinyl chloride. Vinyl chloride degrades to ethylene and will completely degrade through the acetylene pathway. Several microorganisms are capable of anaerobic PCE and TCE biodegradation. The dehydrogenase enzyme can reductively dehalogenate TCE (into both cis and trans-DCE). By looking for the breakdown species of PCE and/or TCE we can better understand the reduction-oxidation state of the ground water and deploy efficient treatment options.

In the Gore-Sorber ${ }^{\mathrm{TM}}$ screening study, 39 soil vapor samples were deployed and one module was installed into a monitor well (W-1414) in order to compare the Gore-Sorber ${ }^{\mathrm{TM}}$ VOC signature to that found in ground water. Table 2 presents the results of the standard aqueous VOC analysis (EPA 601) compared to the Gore-Sorber ${ }^{\mathrm{TM}}$ VOC analysis for monitor well W-1414. Although few VOC degradation products have been detected in the archived ground water data for this well, possibly some anaerobic degradation products were detected from analyses of the Gore-Sorber ${ }^{\mathrm{TM}}$ module installed into this well. The PCE/TCE degradation products may be present in the ground water but are not reported due to the detection limits of EPA 601 analysis.

Despite the presence of small quantities of PCE/TCE breakdown products found in well $\mathrm{W}-1414$, the overwhelming geochemical evidence indicates that LLNL ground water is very oxidized, which largely precludes reductive dehalogenation reactions for chlorinated ethenes and ethanes. There is no significant evidence for reductive dehalogenation of PCE to TCE in the B419/511 area of the LLNL site. Hydrolysis rates for most of the chlorinated ethenes are extremely slow and most likely have no significant impact on the concentrations of these chemicals in LLNL ground water (Liu and Narasimhan, 1989; McNab and Narasimhan, 1994). The lack of 
reductive dehalogenated products in well W-1414 ground water supports this hypothesis. A recent $\mathrm{pH}$ value of 7.1 units, dissolved oxygen of $5.2 \mathrm{mg} / \mathrm{L}$, sulfide of $0.00 \mathrm{mg} / \mathrm{L}$ and a total alkalinity of $280 \mathrm{mg} / \mathrm{L}$ define the water (W-1414) as neutral, aerobic and moderately hard. The presence of some products associated with anaerobic degradation pathways and 1,2 DCA (a breakdown product of trichloroethane, TCA) in the Gore-Sorber ${ }^{\mathrm{TM}}$ sample from well W-1414 may suggest localized areas depleted of oxygen undergoing anaerobic degradation pathways. This may be a good location to review the feasibility of in situ bioremediation techniques such as those used at the TCE plume at Moffet Field in Mountain View, California.

Table 2. Standard ground water sample versus Gore-Sorber ${ }^{\mathrm{TM}}$ sample analysis of well $\mathrm{W}-1414^{\mathrm{a}}$.

\begin{tabular}{lcc}
\hline \hline \multicolumn{1}{c}{ Analyte } & Aqueous sample $\mu \mathrm{g} / \mathrm{L}$ & $\begin{array}{c}\text { Gore-Sorber }{ }^{\mathrm{TM}} \text { sample } \\
\mu \mathrm{g} / \text { sorber }^{\mathrm{b}}\end{array}$ \\
\hline cis, trans 1,2-DCE & $<10.0$ & 0.35 \\
trans 1,2-DCE & $<5.0$ & 0.26 \\
cis 1,2-DCE & $<5.0$ & 0.09 \\
1,1-DCE & $<5.0$ & 1.35 \\
1,1-DCA & $<5.0$ & 0.36 \\
1,1,1-TCA & $<5.0$ & 0.08 \\
1,2 DCA & 50.0 & 10.46 \\
TCE & 2,700 & 221.17 \\
PCE & 230 & 59.74 \\
1,4 DCB & $<5.0$ & $\mathrm{ND}$ \\
VC & $<5.0$ & 1.02 \\
Freon 113 & $<5.0$ & 0.39 \\
\hline \hline Note: & & \\
ND = Non-detection. & \\
a W-1414 analysis from 6/7/00, GWE 542 ft. MSL. & \\
b Units denote vapors recovered from a sample module; Gore-Sorber & \\
to aqueous data. &
\end{tabular}

\subsection{Conclusions and Recommendations}

1. The Gore-Sorber ${ }^{\mathrm{TM}}$ data matches well with the ground water plume maps. This indicates that Gore-Sorber ${ }^{\mathrm{TM}}$ modules are a useful, cost-effective tool to evaluate less characterized areas. Soils analysis from this region was of limited value in locating contaminant source areas.

2. Three potential source area locations in the B419/511 study area were found (1) west of B513, (2) north of B511, and (3) north of B419 in the fenced yard. Each of these source areas had a different contaminant signature.

3. Ground water data indicated the potential for a contaminant source to HSU 5 in the B611 area. An additional Gore-Sorber ${ }^{\mathrm{TM}}$ survey is recommended as a preliminary survey to determine where high concentrations are located between B511 and B518 and B612 and T6179. 
4. The B419/511/514 area ground water contamination is in an area of low permeability and thin saturated thickness. The first saturated zone beneath B419 is on a ground water divide with water flowing northeast and west with a hydraulic gradient of about 0.02 . This makes the application of pump and treat difficult, and indicates a Phase Source Area Remediation (PSR) approach of soil vapor extraction (SVE), electroosmosis (EO), dynamic underground stripping (DUS), and/or in situ microbial treatment is advised for this location.

5. The B518 ground water plume responded well to pump and treat because of the high permeability sediments in HSU 5 at this location. The TFE-SE plume in HSU-5 is anticipated to produce similar results to the B518 area due to similar permeability trends.

6. The potential for abiotic degradation is not favorable in the B419/511 area; however, the feasibility of in situ bioremediation should be reviewed.

\subsection{References}

BeLue A. and D. J. Finley (1999), Building 419 RCRA Closure Project Final Report, Environmental Protection Department, Lawrence Livermore National Laboratory, Livermore, CA (UCRL-AR-133452).

Closure Plan for the Building 419 Size Reduction Unit and Solidification Unit, 1994 Environmental Protection Department, Lawrence Livermore National Laboratory, Livermore, CA (UCRL-AR118071), EPA \#CA2890012584.

Isherwood, W. F., C. H. Hall and M. D. Dresen (Eds.) (1990), CERCLA Feasibility Study for the LLNL Livermore Site, Lawrence Livermore National Laboratory, Livermore, CA (UCRL-AR104040).

Liu C. W. and T. N. Narasimhan (1989), "Redox-Controlled Multiple-Species Reactive Chemical Transport 2, Verification and Application," Water Resource Res. 25:883-910.

McNab W. W., T. N. Narasimhan (1994), "Degradation of Chlorinated Hydrocarbons and Groundwater Geochemistry: A Field Study," Environ. Sci. Technol. 28:769-775. 


\section{Figures}



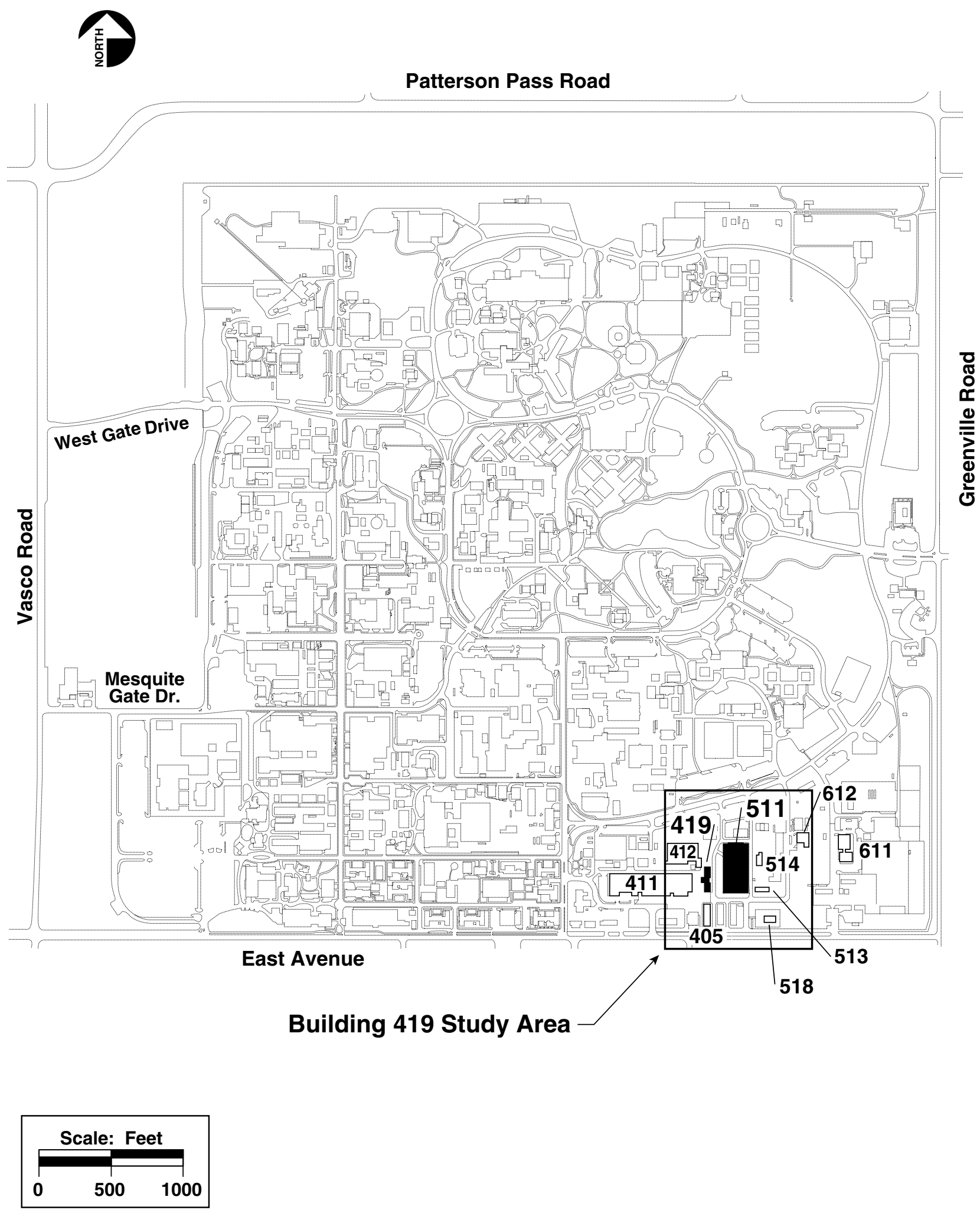

ERD-LSR-00-0148

Figure 1. Location of the Building 419/511 Study Area. 


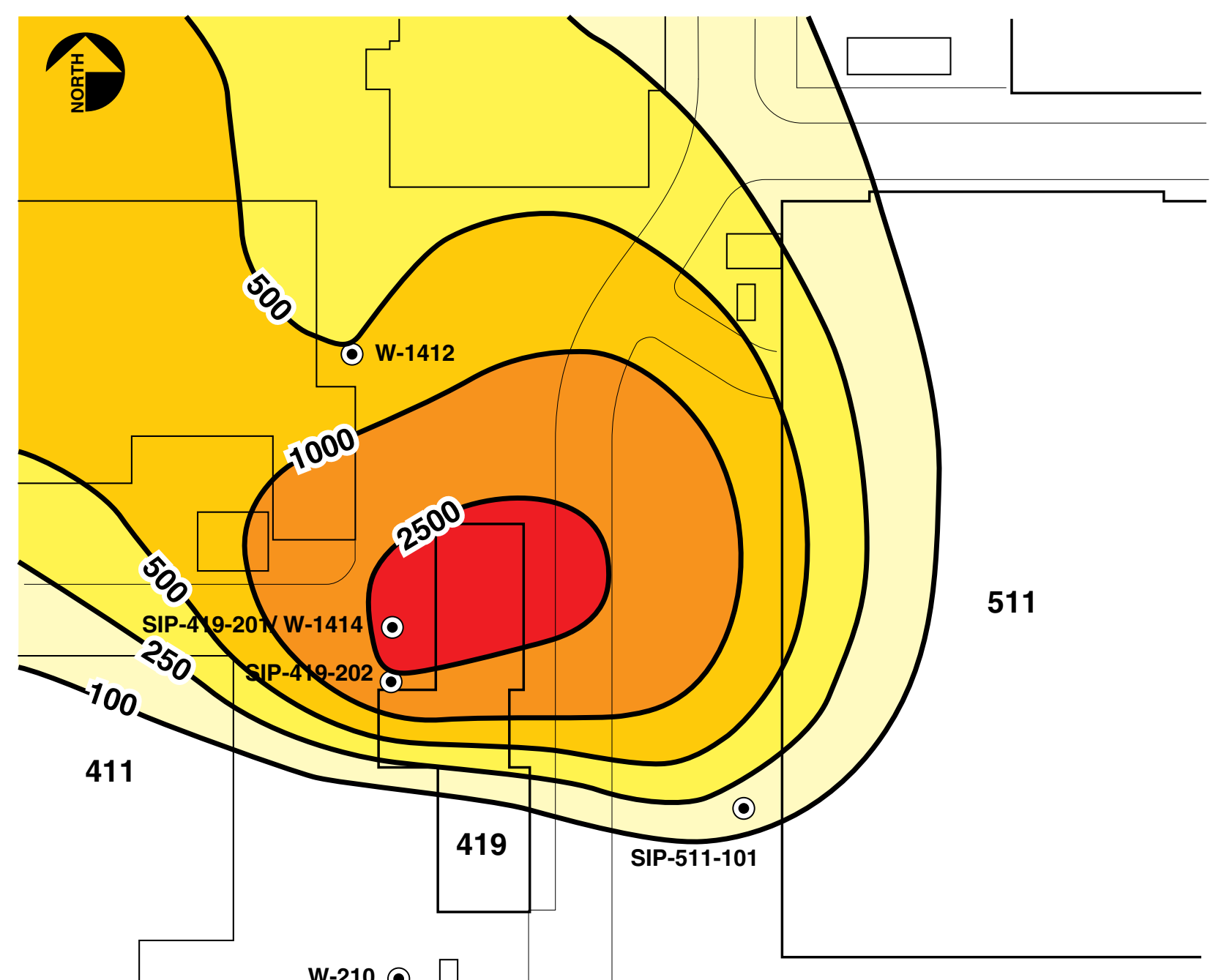

W-210 $\square$
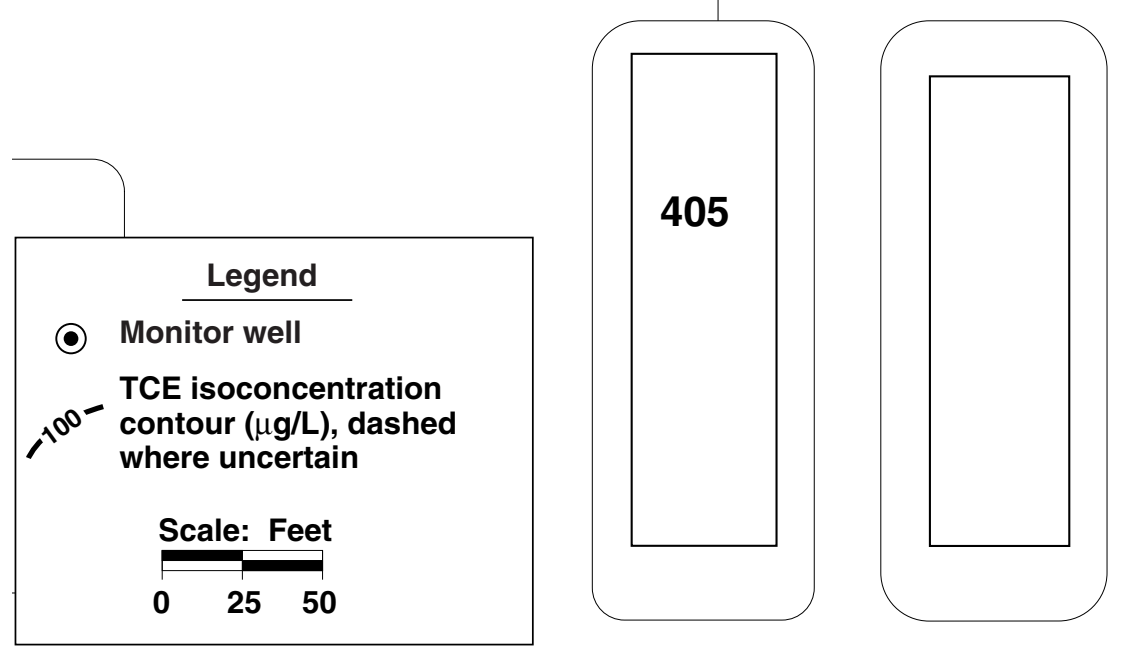

First Street

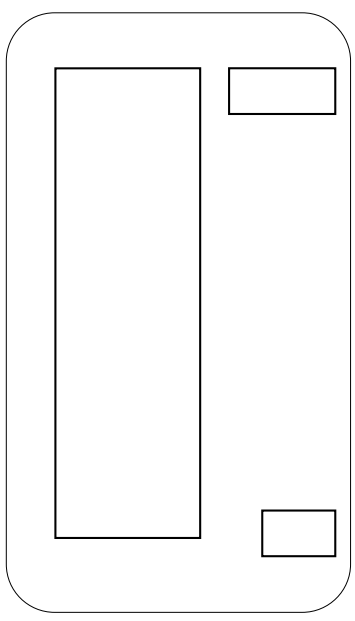

ERD-LSR-00-0141

Figure 2. HSU 3A TCE concentrations, 4th quarter 2000. 


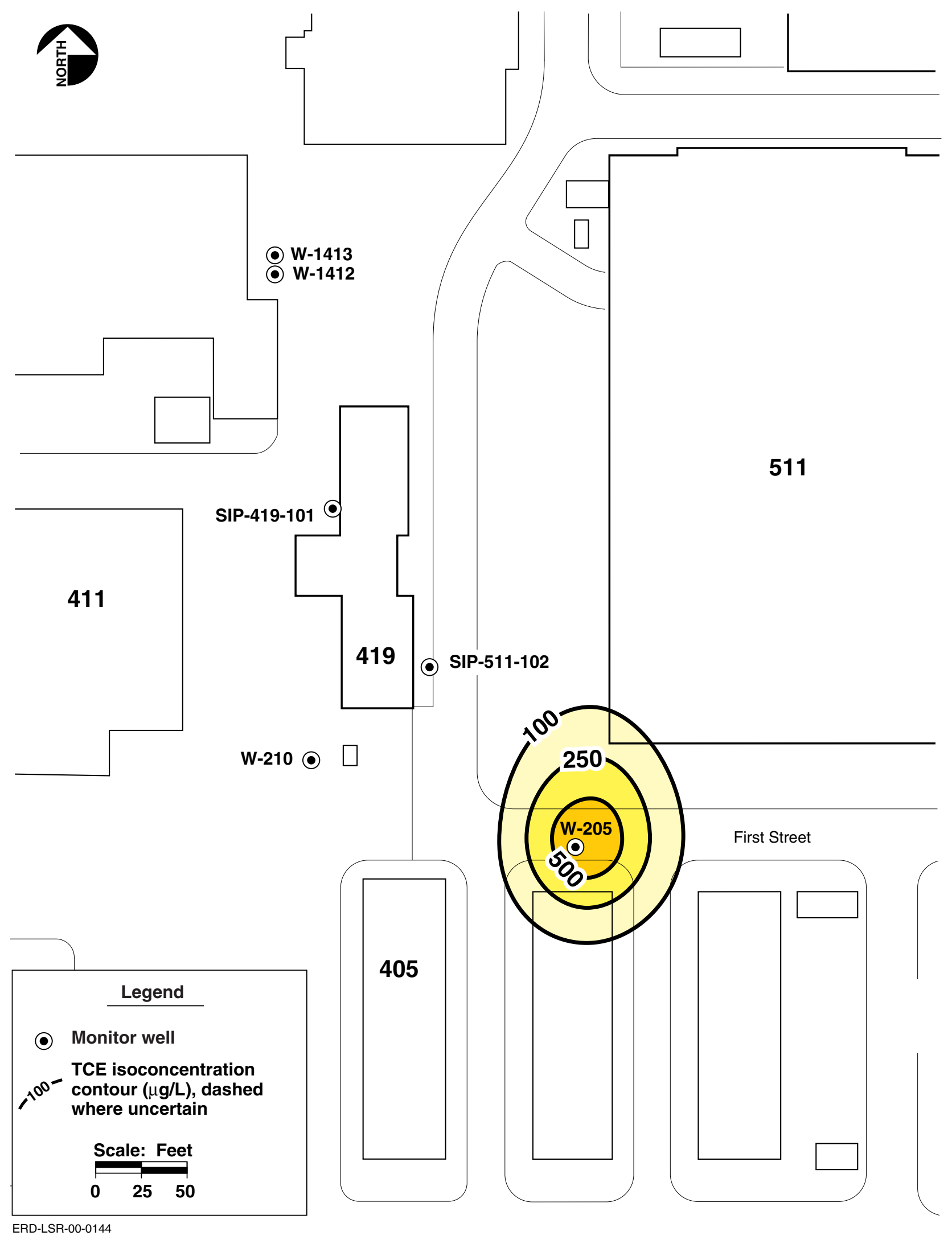

Figure 3. HSU 3B TCE concentrations, 4th quarter 2000. 


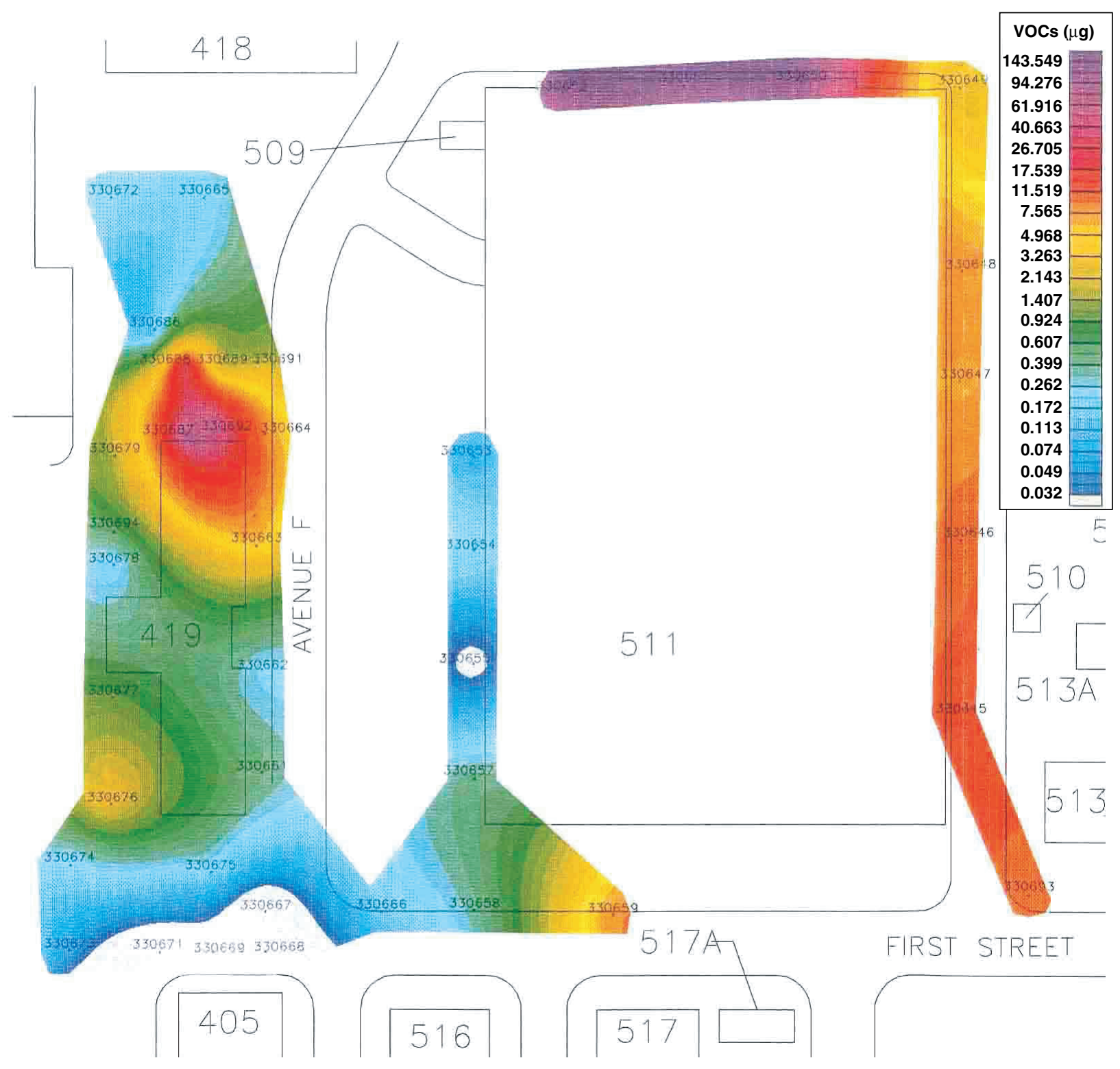

From W. L. Gore \& Associates, Inc., 2000

\section{Scale: Feet \\ $0 \quad 25 \quad 50$}

ERD-LSR-01-0047

Figure 4. Volatile organic compounds (VOCs) soil vapor contours around Buildings 419 and 511, LLNL. 


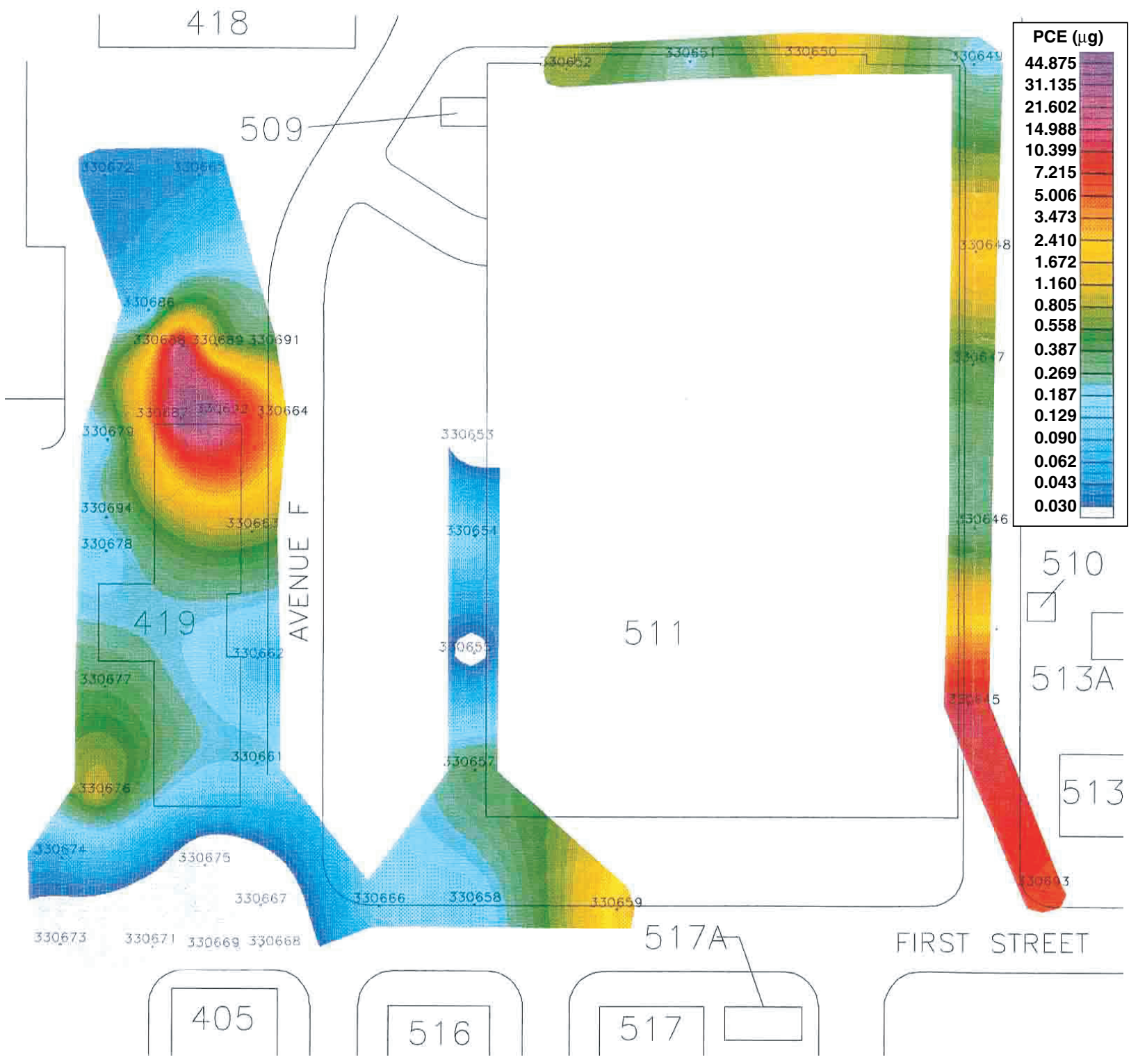

From W. L. Gore \& Associates, Inc., 2000

\section{Scale: Feet \\ $0 \quad 25 \quad 50$}

ERD-LSR-01-0048

Figure 5. Tetrachloroethene (PCE) soil vapor contours around Buildings 419 and 511, LLNL. 


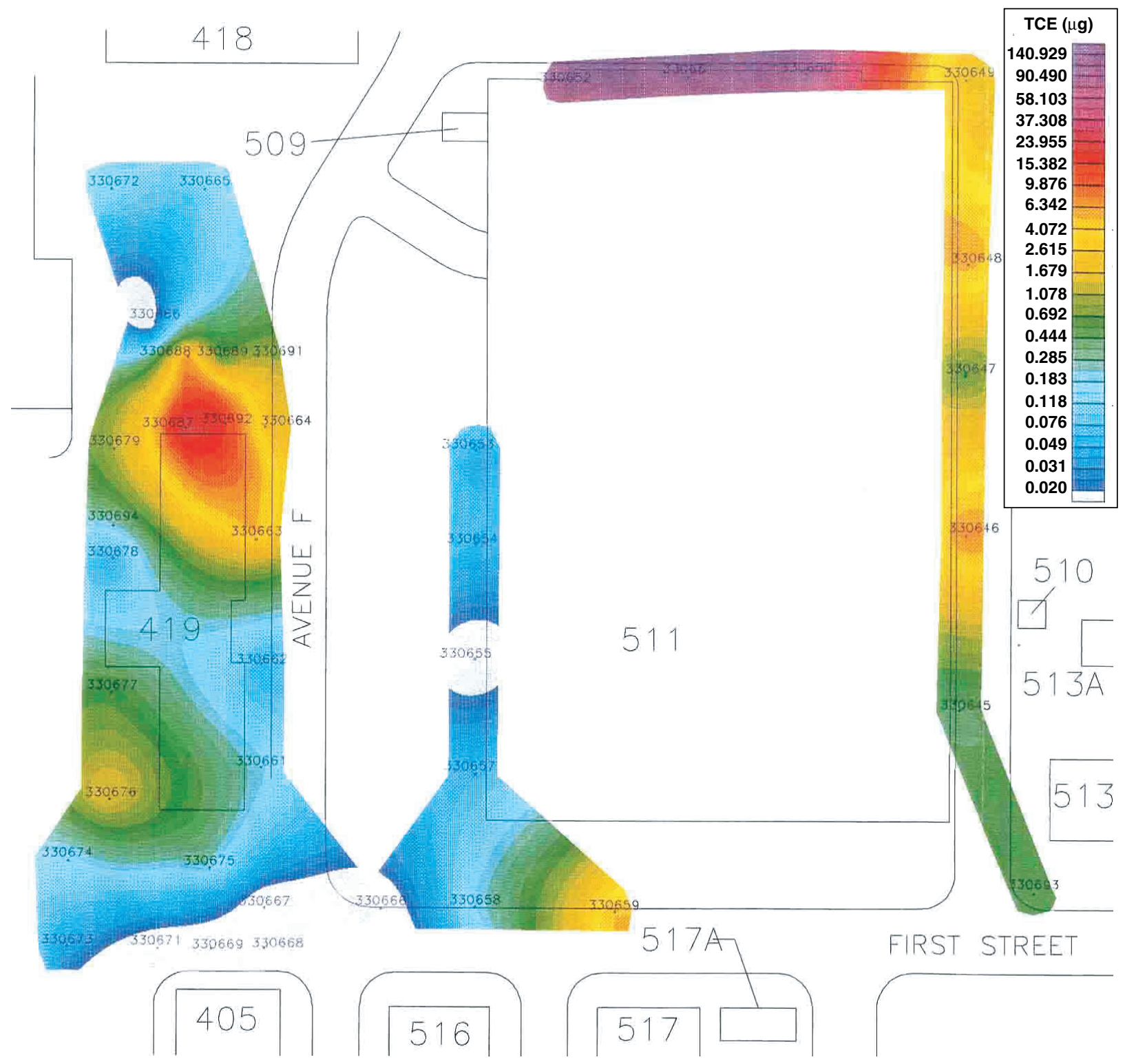

From W. L. Gore \& Associates, Inc., 2000

Scale: Feet

$0 \quad 25 \quad 50$

ERD-LSR-01-0049

Figure 6. Trichloroethene (TCE) soil vapor contours around Buildings 419 and 511, LLNL. 


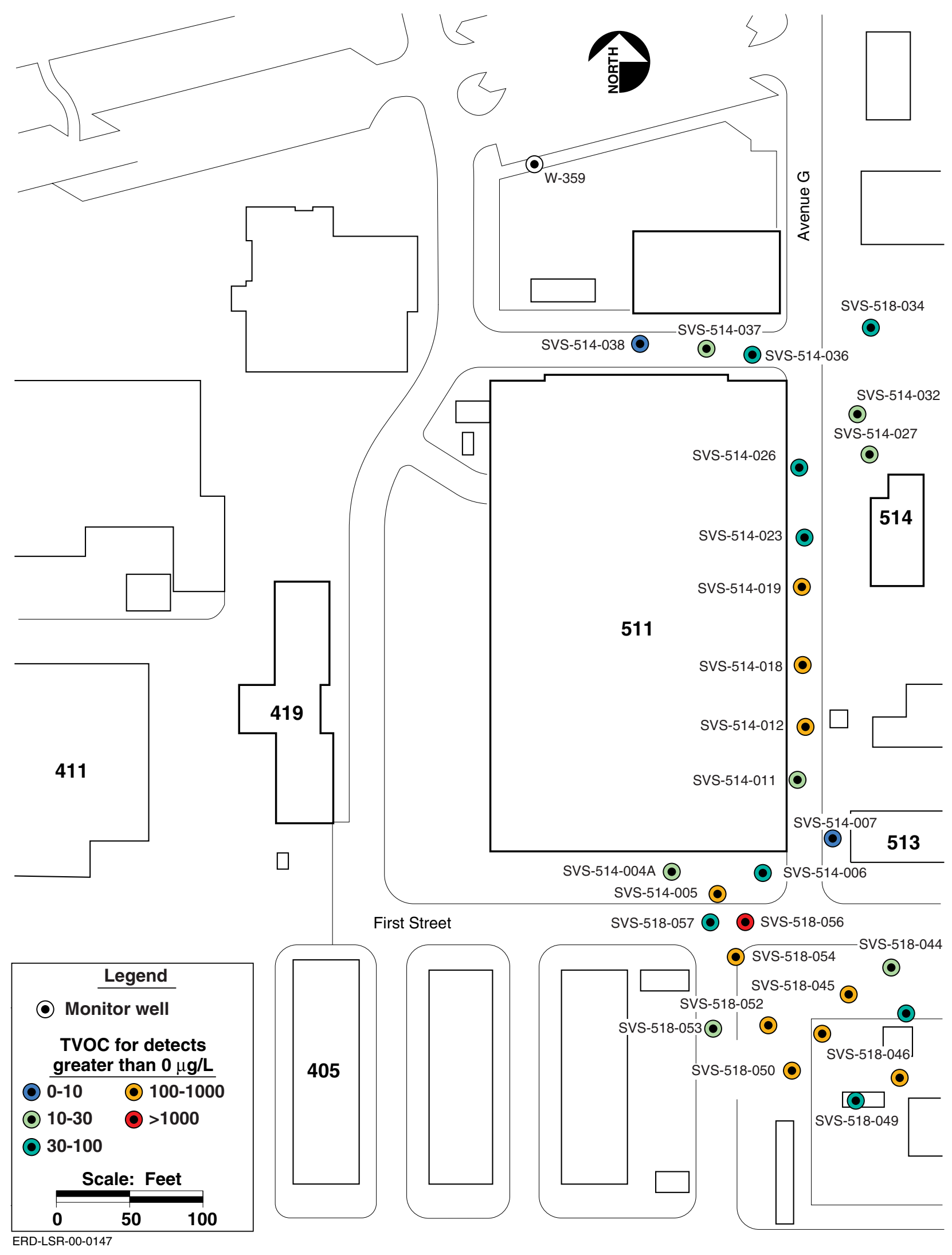

Figure 7. 1989 total VOCs soil vapor survey. 


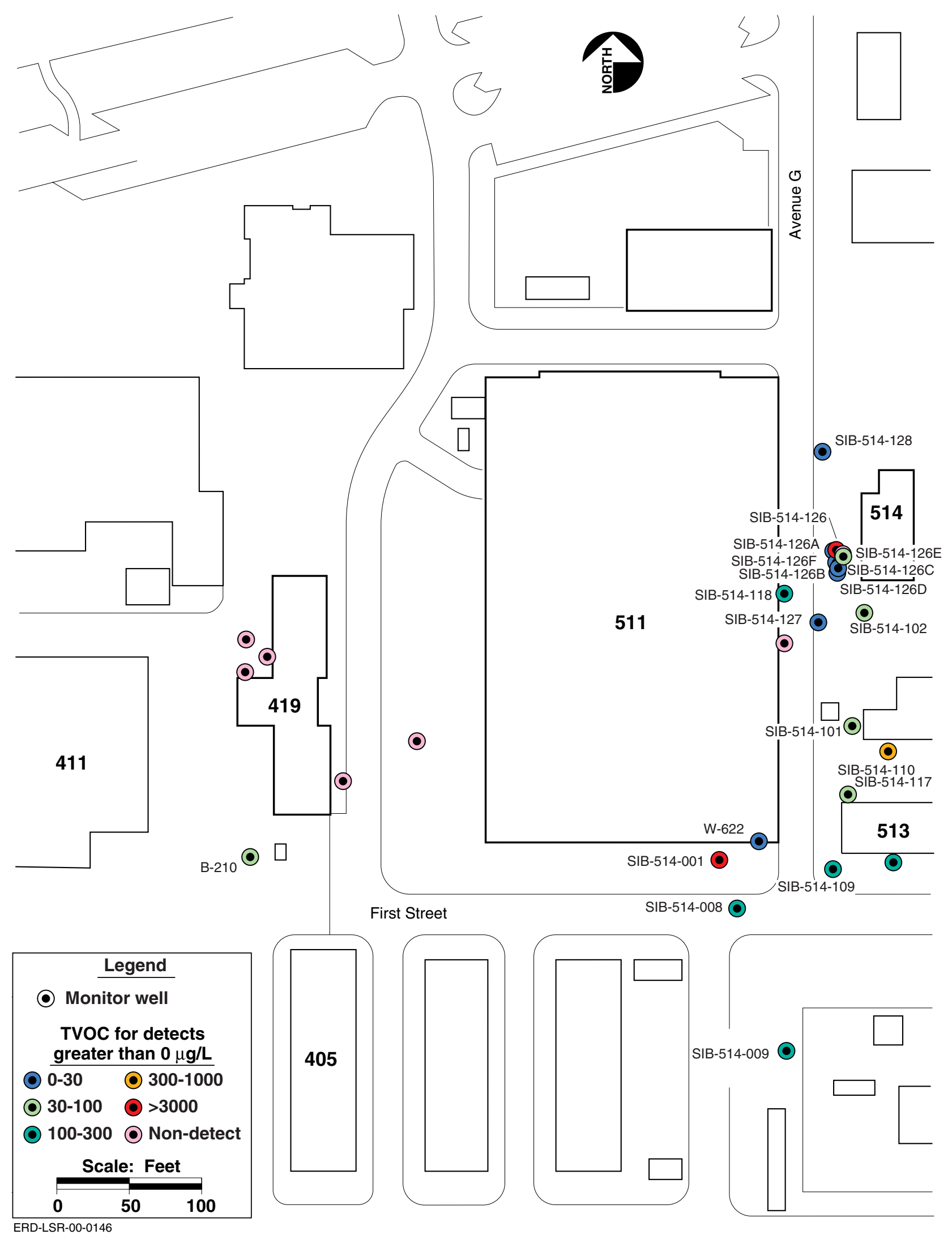

Figure 8. Near surface soil (0-12 ft) plume history analysis for total VOCs (data from 1984 and 1989). 


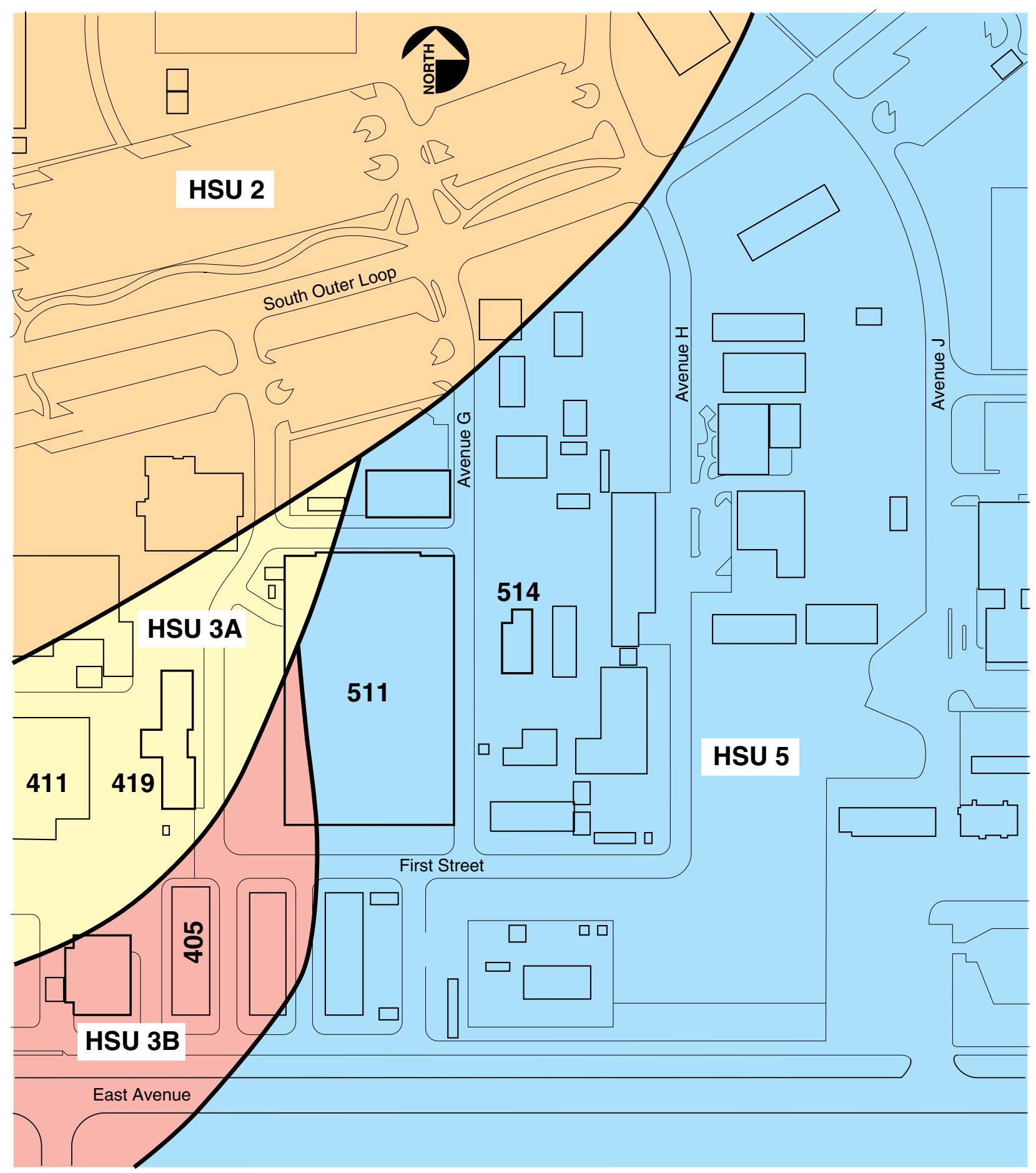

Scale: Feet

$0 \quad 50 \quad 100$

ERD-LSR-00-0140

Figure 9. The first saturated hydrostratigraphic unit in the southeast portion of LLNL. 
$\stackrel{\text { A }}{\text { West }}$

B411

B419

B511
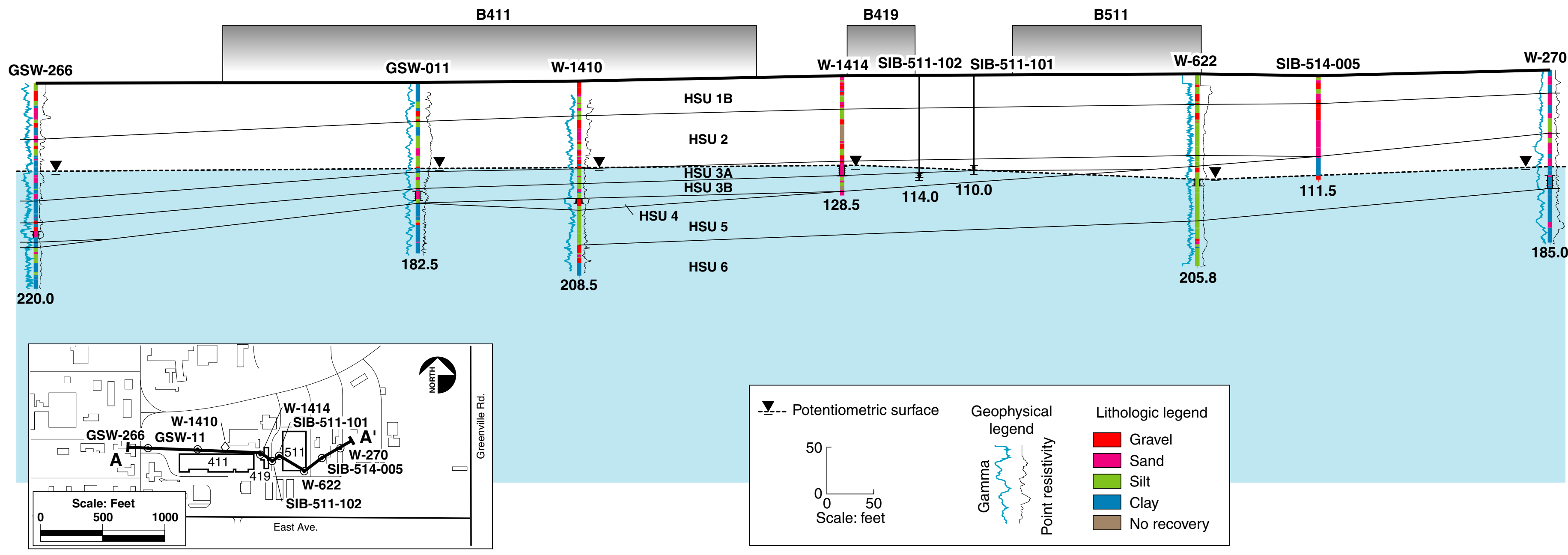

\begin{tabular}{|c|c|c|}
\hline - & $\begin{array}{l}\text { Geophysical } \\
\text { legend }\end{array}$ & Lithologic legend \\
\hline 50 & & Gravel \\
\hline & & Silt \\
\hline $\begin{array}{l}50 \\
\text { Scale: feet }\end{array}$ & $\mathbb{\widetilde { D }}\{\xi$ & $\begin{array}{l}\text { Clay } \\
\text { No recovery }\end{array}$ \\
\hline
\end{tabular}



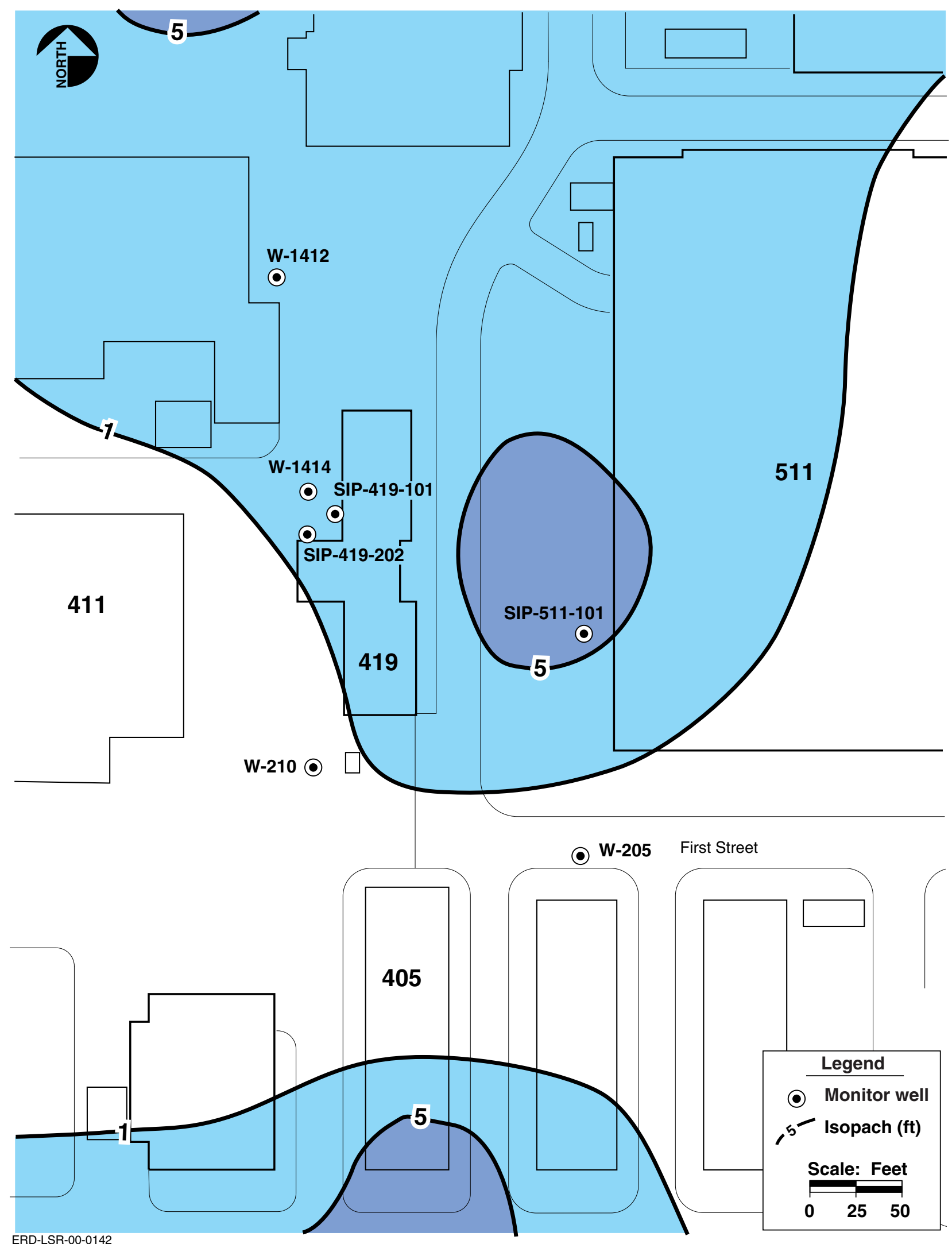

Figure 11. HSU 3A, Isopach of moderate to very high permeability sediments. Isopachs represent the cumulative thickness of sediments, such as sands, within an HSU. 


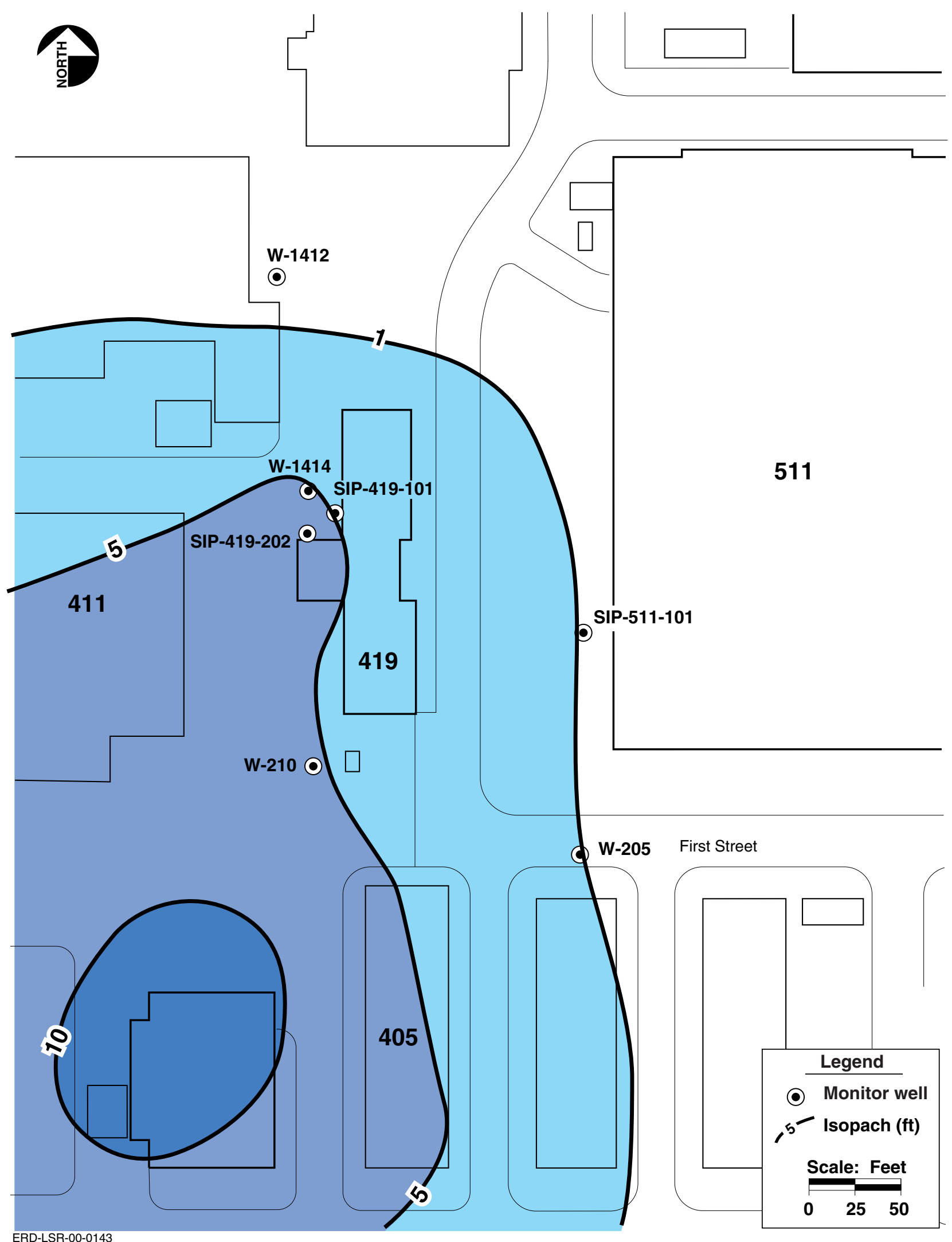

Figure 12. HSU 3B, Isopach of moderate to very high permeability sediments. 


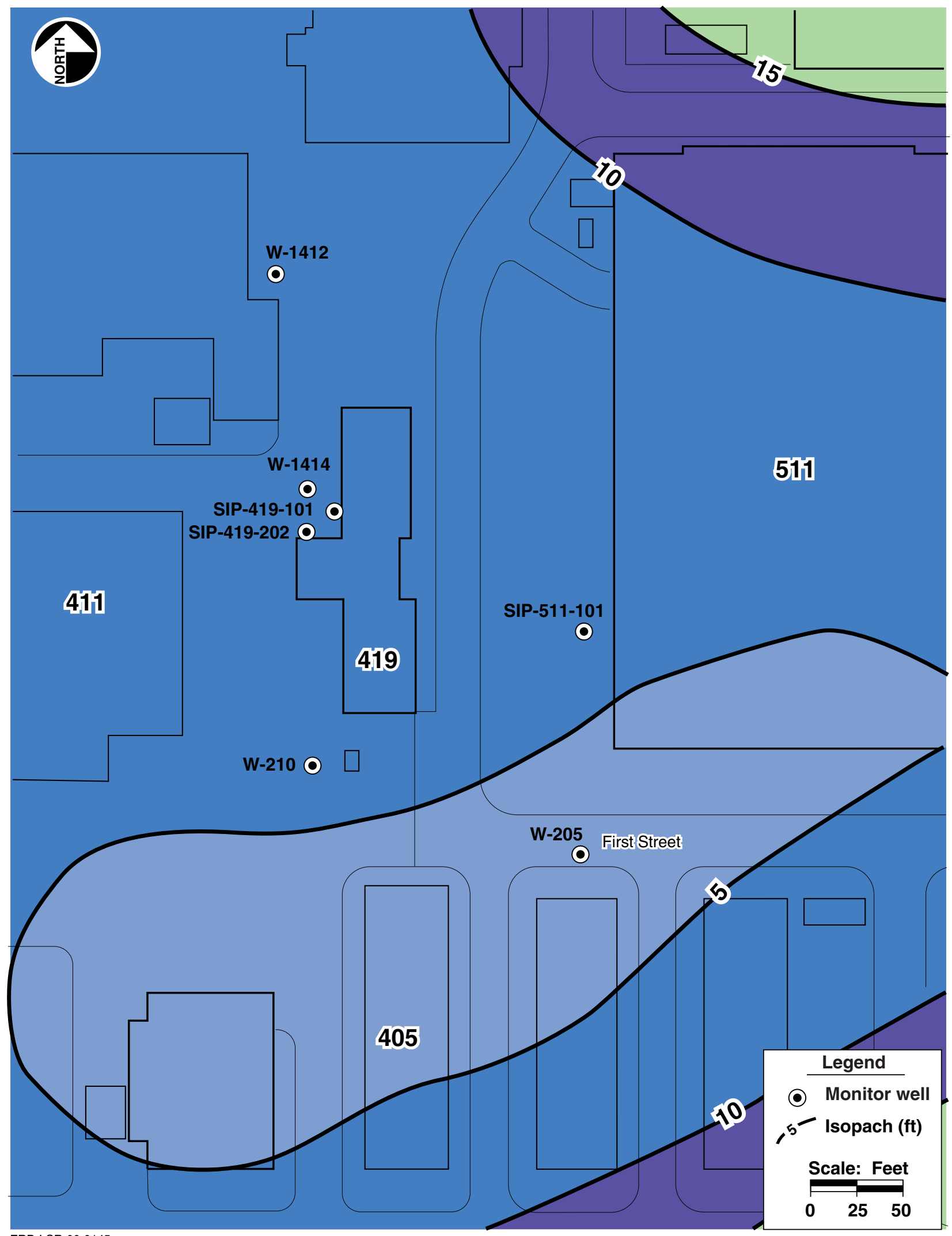

ERD-LSR-00-0145

Figure 13. HSU 5, Isopach of moderate to very high permeability sediments. 